\title{
THE EFFECTS OF ADDING MORINGA OLEIFERA LEAVES EXTRACT ON RABBIT DOES' MILK PRODUCTION AND MAMMARY GLAND HISTOLOGY
}

\author{
Setiasih ${ }^{1,2}$, Wahjuningsih Sri ${ }^{1}$, Winarsih $\mathrm{Sri}^{3}$, Soetanto Hendrawan ${ }^{1 *}$ \\ ${ }^{1}$ Faculty of Animal Husbandry, University of Brawijaya, Indonesia \\ ${ }^{2}$ Institute Assessment of Agriculture Technology, Indonesian Agricultural Research and \\ Development Agency, Indonesia \\ ${ }^{3}$ Faculty of Medicine, University of Brawijaya, Indonesia \\ *E-mail: hendrawan07@ub.ac.id
}

\begin{abstract}
The objective of this study was to examine the effects of adding Moringa leaves extracts on rabbit does' milk production and histological changes of mammary glands during their lactation phase. Three different solvents, which are n-hexane, ethanol and mixed of nhexane and ethanol (50: 50), were used to extract Moringa leaves powder (MLP). Moringa extract was given to the does' feed by seven different treatments: $0 \%$ dosage (without extract), $0.13 \%$ dosage of HeEF, $0.26 \%$ dosage of HeEF, $0.37 \%$ dosage of EtEF, $0.74 \%$ dosage of EtEF, $0.54 \%$ dosage of EtCE and $1.08 \%$ dosage of EtCE. Each treatment was replicated at four does. The variables were dry matter consumption, average does' daily milk production, bunnies' daily weight, and the does' mammary gland histology. The milk production was measured twice per day in the morning (7 a.m.) and the evening (4 p.m.), obtained from the bunnies' weight gap before and after suckling. The results showed that there was a significant difference $(P<5 \%)$ in treatments' effect on dry matter consumption, daily milk production and bunnies' average daily gain (ADG). From the results, treatments with the highest daily milk production were $0.54 \%$ EtCE $(134.70 \pm 5.77 \mathrm{~g} /$ day $)$ and $0.26 \%$ EtEF (128.83 $\pm 10.11 \mathrm{~g} /$ day). The potential effect of Moringa leaves extract on the milk production was shown by an overview of mammary gland alveoli, which indicates the increasing number of the epithelial cells as well as the alveoli number and size.
\end{abstract}

\section{KEY WORDS}

Rabbit, Moringa leaves extract, milk production, mammary gland histology, galactagogue.

Nutrients sufficiency and hormones affect milk synthesis and production. Some people are using a compound called 'galactagogue' to optimize the trigger hormones. Galactagogues are drugs or substances believed to assist in the initiation, maintenance or augmentation of milk production (Rajagopal et.al, 2016; Wadha et.al, 2013). Some drugs serve as galactagogues, such as metoclopramide, domperidone, chlorpromazine, sulpiride, oxytocin, growth hormone, thyrotropin-releasing hormone, and medroxyprogesterone (Zuppa et.al, 2010). A few researchers reported that some plants function as galactagogue herbs such as Moringa oleifera (Estrella et.al, 2000), Sauropusandrogynus (Akbar et.al, 2013), Fenugreek (Trigonellafoenumgraecum) and Silymarin (Silybummarianum) (Zuppa, et.al, 2010). Antonet et.al (2003) reported that moringa leaves effects to accelerate milk secretion are similar to domperidone and metoclopramide. Most people prefer galactagogue herbs as they have fewer side effects.

Moringa oleifera leaves potentially increase milk production of nursing mothers in the Philippines (Estrella et.al, 2000; Almirante and Lim, 1996), of cows (Sanchez et.al, 2005; Mendieta-Aracia, 2011), of goats (Soetanto et.al, 2010), of Wistar rats (Pearl et.al, 2013; Mutiara et.al, 2012), and of rabbits (Alemede et.al, 2014). This potential is associated with the leaves' having plenty of nutrients content such as amino acids complete, vitamins and others that are used as a synthesis of milk; therefore, dairy farming highly recommends using Moringa oleifera leaves as feedstuff (Mendiata-Aracia et.al, 2010).

In addition, bioactive compounds contained in Moringa oleifera are considered to function as a galactagogue. According to Almirante and Lim (1996), milk production is 
affected by several processes: (1) mammogenesis, which is the growth of the mammary gland namely ducts and alveoli with estrogen, progesterone, prolactin and growth hormone (2) lactogenesis, which is the initiation of milk secretion influenced by the development of mammary glandular secretion and distribution of estrogen and progesterone to the fetus and placenta (3) galactocentric, which is influenced by the oxytocin hormone promoting breast contraction to produce milk from the myoepithelial cell to the milk ducts, and (4) galactopoiesis, which is milk production maintenance, whose role is played by the prolactin hormone.

Galactagogue compound is related to the hormones; so, it is assumed that phytohormone in Moringa oleifera leaves plays a part in increasing milk production. The leaves contain phytosterol and isoflavone as the phytoestrogen compound (Leone et.al, 2015) which has estrogenic activity due to its similar chemical structure to estradiol (Ryokkynen, 2006). Phytosterols are steroids dissolved in non-polar solvents such as nhexane; while isoflavones are a group of flavonoids optimally extracted with ethanol (Kudou et.al, 1991).

The objectives of this study were to examine the galactagogue effects of MLP extracts with different solvents on the milk production, ADG of bunnies and does, as well as rabbits' mammary gland histology.

\section{MATERIALS AND METHODS OF RESEARCH}

A hexane extract fraction (HeEF), an ethanolic extract fraction (EtEF) and an ethanolic crude extract (EtCE) of MLP were used in this study. The MLP was produced by Moringa Indonesia in Blora, Central Java, Indonesia. The particle size of the MLP was 80 mesh.

EtCE was produced by extraction of MLP using 96\% ethanol (1: 8; w/v). Maceration was conducted for 24 hours and was stirred by the shaker; after that, the filtrate was evaporated and freeze-dried for 30 hours. Meanwhile, HeEF and EtEF were produced by extraction using a mixed solvent of $96 \%$ ethanol and n-hexane (50: 50; v: v). The ratio of MLP and the solvent was 1: $8(\mathrm{w}: \mathrm{v})$. Then, the filtrate was separated by separation funnel. The $n$-hexane solution was at the top layer and the ethanol solution was at the bottom layer. Next, each fraction solution was evaporated: the n-hexane was evaporated by 72 mbar and the ethanol was evaporated by 175 mbar. After that, the filtrates were freeze-dried: HeFE for 24 hours and EtFE for 30 hours.

The types of phytosterol and isoflavone compounds in MLP extracts were identified qualitatively through Liquid Chromatography-Mass Spectrometry (LCMS) in Instrumental Laboratory of Politeknik Negeri Malang. The identification of isoflavone was based on Konar et.al. (2012), while phytosterol was based on Miller and Schnute (2014).

The research involved twenty-eight heads of New Zealand White lactation rabbits on second to the third parity, whose average body weight was $2.1 \mathrm{~kg}$ (block-I), $2.35 \mathrm{~kg}$ (BlockII), $2.64 \mathrm{~kg}$ (block-III) and $2.85 \mathrm{~kg}$ (block-IV). The does were divided into four groups based on their initial body weight and allotted into a randomized complete block (RCB) design (Steel and Torrie, 1980), using seven treatments and four replications.

The treatments were E0 (pellet without MLP extract), $0.13 \%$ HeEF0 (feed containing HeEF equal $10 \%$ MLP in pellet), $0.26 \%$ HeEF (feed containing HeEF equal $20 \%$ MLP in pellet), $0.37 \%$ EtEF (feed containing EtEF equal $10 \%$ of MLP in pellet), $0.74 \%$ EtEF (feed containing EtEF equal 20\% MLP in pellet), 0.54\% EtCE (feed containing EtCE equal $10 \%$ MLP in pellet) and $1.08 \%$ EtCE (feed containing EtCE equal $20 \%$ MLP in pellet). Table 1 presents the composition of each treatment's feedstuff and Table 2 presents the nutrient content of pellet and forage.

The does were given treatment feed immediately after parturition. Preliminary feeding was done before mating. The ration consisted of $40 \%$ forage and $60 \%$ pellet. The rabbits were fed twice: with pellets at 7:00 a.m and with forage at $3.00 \mathrm{pm}$.

The variables were milk production, weaning weight, bunnies' daily body weight gain, does' weight gain during lactation, mammary gland histology, the number of epithelial cells, as well as the number and size of alveoli. The milk production measurement was conducted 
by weighing the bunnies before and after feeding on day- 1 to day-21 after birth because at that time the bunnies were still exclusively suckling the doe's milk. The rabbits were housed in individual cages and bunnies were separated from its doe until they were 21-days old. Milk production was calculated by the difference in the total weight of the bunnies after and before feeding. Bunnies were suckling milk twice a day, which was at 7: $30 \mathrm{a} . \mathrm{m}$ and at 4: $30 \mathrm{pm}$. The weaning weight of bunnies was measured when they were 21-days old. The bunnies' ADG was calculated by the difference of the weaning weight at 21-days and the birth weight divided by 21 .

Table 1 - The Feedstuff Composition of Each Treatment

\begin{tabular}{|c|c|c|c|c|c|c|c|}
\hline Feedstuff & E0 & HeEF $0.13 \%$ & HeEF $0.26 \%$ & EtEF $0.37 \%$ & EtEF $0.74 \%$ & ECE $0.54 \%$ & ECE $1.08 \%$ \\
\hline Forage (\%) & 40 & 40 & 40 & 40 & 40 & 40 & 40 \\
\hline Broccoli leaves (\%) & 100 & 100 & 100 & 100 & 100 & 100 & 100 \\
\hline Total (\%) & 100 & 100 & 100 & 100 & 100 & 100 & 100 \\
\hline Pellet (\%) & 60 & 60 & 60 & 60 & 60 & 60 & 60 \\
\hline Polished rice bran (\%) & 70 & 69.87 & 69.74 & 69.63 & 69.26 & 69.46 & 68.93 \\
\hline Fish meal (\%) & 5 & 5 & 5 & 5 & 5 & 5 & 5 \\
\hline Coconut cake (\%) & 20 & 20 & 20 & 20 & 20 & 20 & 20 \\
\hline Top mix $(\%)^{*}$ & 0.5 & 0.5 & 0.5 & 0.5 & 0.5 & 0.5 & 0.5 \\
\hline Salt (\%) & 0.5 & 0.5 & 0.5 & 0.5 & 0.5 & 0.5 & 0.5 \\
\hline Maize meal (\%) & 3.5 & 3.5 & 3.5 & 3.5 & 3.5 & 3.5 & 3.5 \\
\hline Tapioca flour (\%) & 0.5 & 0.5 & 0.5 & 0.5 & 0.5 & 0.5 & 0.5 \\
\hline HeEF (\%) & 0 & 0.13 & 0.26 & 0 & 0 & 0 & 0 \\
\hline EtEF (\%) & 0 & 0 & 0 & 0.37 & 0.74 & 0 & 0 \\
\hline EeCE (\%) & 0 & 0 & 0 & 0 & 0 & 0.54 & 1.07 \\
\hline Total (\%) & 100 & 100 & 100 & 100 & 100 & 100 & 100 \\
\hline
\end{tabular}

${ }^{*}$ Every $10 \mathrm{~kg}$ of Top mix contains 12.000.000 IU of Vitamin A, 2.000.000 IU of Vitamin D3, 8.000 IU of Vitamin E, $32.000 \mathrm{mg}$ of Vitamin K, $2000 \mathrm{mg}$ of Vitamin B1, $5000 \mathrm{mg}$ of Vitamin B2, $500 \mathrm{mg}$ of Vitamin B6, $12000 \mathrm{mg}$ of Vitamin B12, $25000 \mathrm{mg}$ of Vitamin C, $6000 \mathrm{mg}$ of Ca-D-Pantotenate, $40.000 \mathrm{mg}$ of Niacin, $10.000 \mathrm{mg}$ of Cholin Chloride, $30.000 \mathrm{mg}$ of Metheonin, $30.000 \mathrm{mg}$ of Lysine, $120.000 \mathrm{mg}$ of Manganese, $20.000 \mathrm{mg}$ of Iron, $200 \mathrm{mg}$ of lodine, $100.000 \mathrm{mg}$ of Zinc, $200 \mathrm{mg}$ of Cobalt, $4.000 \mathrm{mg}$ of Copper, $10.000 \mathrm{mg}$ of Santoquin, $21.000 \mathrm{mg}$ of Zinc basitracin, and supporting materials up to $10 \mathrm{~kg}$.

Table 2 - The Nutrient Content of Pellet and Forage*

\begin{tabular}{ccc}
\hline Nutrient & Pellet (all treatments combined) & Forage (Broccoli leaves) \\
\hline Dry matter (\%) & 88.75 & 18 \\
Crude Protein (\%) & 18.22 & 27.63 \\
Extract Ether (\%) & 9.2 & 1.06 \\
N-free Extract (\%) & 54.41 & 48.31 \\
Crude Fiber (\%) & 8.79 & 8.28 \\
Ash (\%) & 9.38 & 15.16 \\
Gross energy (kcal/g) & 3188.25 & 2955 \\
\hline
\end{tabular}

*The results of the proximate analysis at Animal Nutrition and Feed Laboratory, Faculty of Animal Husbandry, University of Brawijaya.

The number of epithelial cell and alveoli, alveoli diameter and width were calculated in five microscope field-of-view through 400x magnification using Image Raster 3 Program. Each field-of-view was measured on 10 alveoli. The data were analyzed by ANOVA RCB design using SPSS version-23 (IBM, Harvard University). Provided there was a significant difference, it proceeded to be analyzed by LSD (Least Significant Difference).

The data about milk production and reproductive performance were analyzed using SPSS version-23 (IBM, Harvard University) with covariance analysis of randomized complete block (RCB) design using the number of bunnies as the covariance. Provided there was a significant difference, it proceeded to be analyzed by LSD.

\section{RESULTS AND DISCUSSION}

Table 3 present the result of identification phytosterol and isoflavone compounds in MLP extracts by LCMS. Both EtCE and EtFE contain isoflavone compounds which positive polarity namely daidzein, biochanin $A$, and glycitein, while formononetin was contained by 
EtFE only. The MPL extracts do not contain genistein, the type of isoflavone commonly found in soybeans. Whereas, both EtCE and HeFE contain phytosterol types consist of lathosterol, campesterol, stigmasterol, and $\beta$-sitosterol.

Table 3 - The Identification of Phytosterol and Isoflavone Compounds in MLP Extracts

\begin{tabular}{|c|c|c|c|c|c|}
\hline \multirow[b]{2}{*}{ Compounds } & \multirow{2}{*}{ Precursor ion } & \multirow[b]{2}{*}{ Product ion } & \multicolumn{3}{|c|}{ Moringa Leaves Extract } \\
\hline & & & EtCE & EtFE & $\mathrm{HeFE}$ \\
\hline \multicolumn{6}{|l|}{ Isoflavone } \\
\hline Daidzein & 252.6 & $223.1 ; 207.7$ & + & + & $\mathrm{Nid}$ \\
\hline Formononetin & 266.6 & $251.6 ; 222.7$ & - & + & $\mathrm{Nid}$ \\
\hline Genistein & 268.6 & $158.6 ; 132.8$ & - & - & $\mathrm{Nid}$ \\
\hline Biochanin A & 282.6 & $267.5 ; 238.6$ & + & + & $\mathrm{Nid}$ \\
\hline Glycitein & 282.6 & $267.5 ; 238.6$ & + & + & $\mathrm{Nid}$ \\
\hline Daidzin & 417.3 & $255.1 ; 199.0$ & - & - & $\mathrm{Nid}$ \\
\hline Ononin & 431.3 & $270.3 ; 269.1$ & - & - & $\mathrm{Nid}$ \\
\hline Genistin & 433.3 & 271.1 & - & - & $\mathrm{Nid}$ \\
\hline Glycitin & 447.3 & $284.9 ; 269.8$ & - & - & $\mathrm{Nid}$ \\
\hline Sisotrin & 447.3 & 285.1 & - & - & $\mathrm{Nid}$ \\
\hline \multicolumn{6}{|l|}{ Phytosterol } \\
\hline Lathosterol & 369.4 & $95.1 ; 81.1$ & + & $\mathrm{Nid}$ & + \\
\hline Campesterol & 383.4 & $161.2 ; 95.0$ & + & $\mathrm{Nid}$ & + \\
\hline Stigmasterol*) & 395.4 & $83.1 ; 83.1$ & + & $\mathrm{Nid}$ & + \\
\hline$\beta$-Sitosterol & 397.4 & $161.0 ; 135.2$ & + & $\mathrm{Nid}$ & + \\
\hline
\end{tabular}

Note: nid $=$ not identified.

Table 4 presents the significant effect of different types and levels of MPL extract administration on feed intake. According to the table, the treatment of $1.08 \%$ EtCE showed the highest dose of ethanol crude extract consumption, which was $375.57 \mathrm{mg} / \mathrm{kg} \mathrm{WB} /$ day. This led to a decrease in feed intake. The treatment of $1.08 \%$ EtCE revealed the lowest feed intake, which was $138.45 \pm 16.59 \mathrm{~g} / \mathrm{head} /$ day. It was only $1.08 \%$ EtCE treatment that showed different feed consumption. Therefore, it is safe to say that the effects of treatment were caused by extract consumption. The highest content of flavonoids was found in $1.08 \% \mathrm{EtCE}$ treatment diet. Flavonoids taste bitter thus reducing feed palatability (Roland et al, 2014).

Table 4 - The Dry Matter Intake and Extract Consumption

\begin{tabular}{lll}
\hline Treatment & Extract Consumption $(\mathrm{mg} / \mathrm{kg} \mathrm{BW} /$ day $)$ & Feed Intake $(\mathrm{g}$ DM/day) \\
\hline E0 & 0 & $144.37 \pm 15.55^{\mathrm{b}}$ \\
HeEF0.13\% & 45.63 & $144.05 \pm 13 .^{19 \mathrm{~b}}$ \\
HeEF0.26\% & 91.26 & $145.82 \pm 14.57^{\mathrm{b}}$ \\
EtEF0.37\% & 129.87 & $145.95 \pm 14.64^{\mathrm{b}}$ \\
EtEF0.74\% & 259.74 & $142.20 \pm 12.68^{\mathrm{b}}$ \\
EtCE0.54\% & 189.54 & $145.95 \pm 12.68^{\mathrm{b}}$ \\
EtCE $1.08 \%$ & 375.57 & $138.45 \pm 16.59^{\mathrm{a}}$ \\
\hline
\end{tabular}

* Superscript differences in the same column indicate significant differences $(P<0.5)$.

Table 5 reveals MLP extract administration in the feed had a significantly different effect $(P<0.5)$ on the does' milk production and reproductive performances. The table demonstrates that the treatments have a significant effect $(\mathrm{P}<0.05)$ on does' daily milk production and bunnies' daily weight gain. The $0.54 \%$ EtCE treatment showed the highest milk production, which was $134.70 \pm 5.77 \mathrm{~g} /$ day. The does' milk production affected bunnies' average daily gain. The $0.26 \%$ HeFE treatment resulted in the highest bunnies' ADG, which was $12.20 \pm 3.86 \mathrm{~g} /$ day; following this, the $0.54 \%$ EtCE treatment result was $10.04 \pm 0.96$ g/day.

Figure 1 indicates the does' average daily milk production in each treatment. It presents the graphic of daily milk production in the treatments. Accordingly, the $0.26 \% \mathrm{HeEF}$ and $0.54 \%$ EtCE treatments showed higher daily milk production than the others. The peak of milk production varied in each treatment, occurring between 9-15 days after parturition. 
The highest peak milk production, which was more than $160 \mathrm{~g} /$ day, was obtained through $0.26 \%$ HeEF and $0.54 \%$ EtCE treatments at 12 days after the does' parturition.

Table 5 - Milk Production and Reproduction Parameters

\begin{tabular}{ccccccc}
\hline Treatment & $\begin{array}{c}\text { Bunny } \\
\text { Size }\end{array}$ & $\begin{array}{c}\text { Bunny Weight } \\
(\mathrm{g})\end{array}$ & $\begin{array}{c}\text { Birth Weight } \\
(\mathrm{g})\end{array}$ & $\begin{array}{c}\text { Daily milk } \\
\text { production }(\mathrm{g})\end{array}$ & $\begin{array}{c}\text { ADG of the } \\
\text { bunny }(\mathrm{g})\end{array}$ & $\begin{array}{c}\text { Changes of BW Does } \\
\text { during suckling }\end{array}$ \\
\hline E0 & $6.75 \pm 2.98$ & $325.4 \pm 105.8$ & $51.14 \pm 15.54$ & $103.69 \pm 14.137^{\mathrm{a}}$ & $7.78 \pm 3.47^{\mathrm{a}}$ & $-180.0 \pm 89,07^{\mathrm{ab}}$ \\
HeEF0.13\% & $5.25 \pm 1.50$ & $255.29 \pm 54.75$ & $50.18 \pm 7.63$ & $98.45 \pm 11.67^{\mathrm{a}}$ & $7.10 \pm 2.94^{\mathrm{a}}$ & $-61.25 \pm 117.64^{\mathrm{b}}$ \\
HeEF0.26\% & $6.25 \pm 2.36$ & $286.32 \pm 84.74$ & $47.45 \pm 6.82$ & $128.83 \pm 10.11^{\mathrm{b}}$ & $12.20 \pm 3.86^{\mathrm{b}}$ & $-50.0 \pm 135.40^{\mathrm{b}}$ \\
EtEF0.37\% & $5.5 \pm 2.38$ & $282.01 \pm 92.40$ & $53.53 \pm 8.18$ & $108.55 \pm 11.78^{\mathrm{a}}$ & $8.13 \pm 3.81^{\mathrm{a}}$ & $0.0 \pm 35.36^{\mathrm{b}}$ \\
EtEF0.74\% & $5.5 \pm 2.08$ & $268.58 \pm 73.60$ & $50.59 \pm 6.40$ & $96.46 \pm 12.35^{\mathrm{a}}$ & $7.35 \pm 4.15^{\mathrm{a}}$ & $6.25 \pm 31.46^{\mathrm{b}}$ \\
EtCE0.54 & $6.0 \pm 0.81$ & $298.26 \pm 48.84$ & $49.73 \pm 5.34$ & $134.70 \pm 5.77^{\mathrm{b}}$ & $10.04 \pm 0.99^{\mathrm{ab}}$ & $-125.75 \pm 65.25^{\mathrm{b}}$ \\
\% & & & $104.04 \pm 6.62^{\mathrm{a}}$ & $6.295 \pm 0.96^{\mathrm{a}}$ & $-286.25 \pm 116.25^{\mathrm{a}}$ \\
\hline
\end{tabular}

* Superscript differences in the same column indicate significant differences $(P<0.05)$.

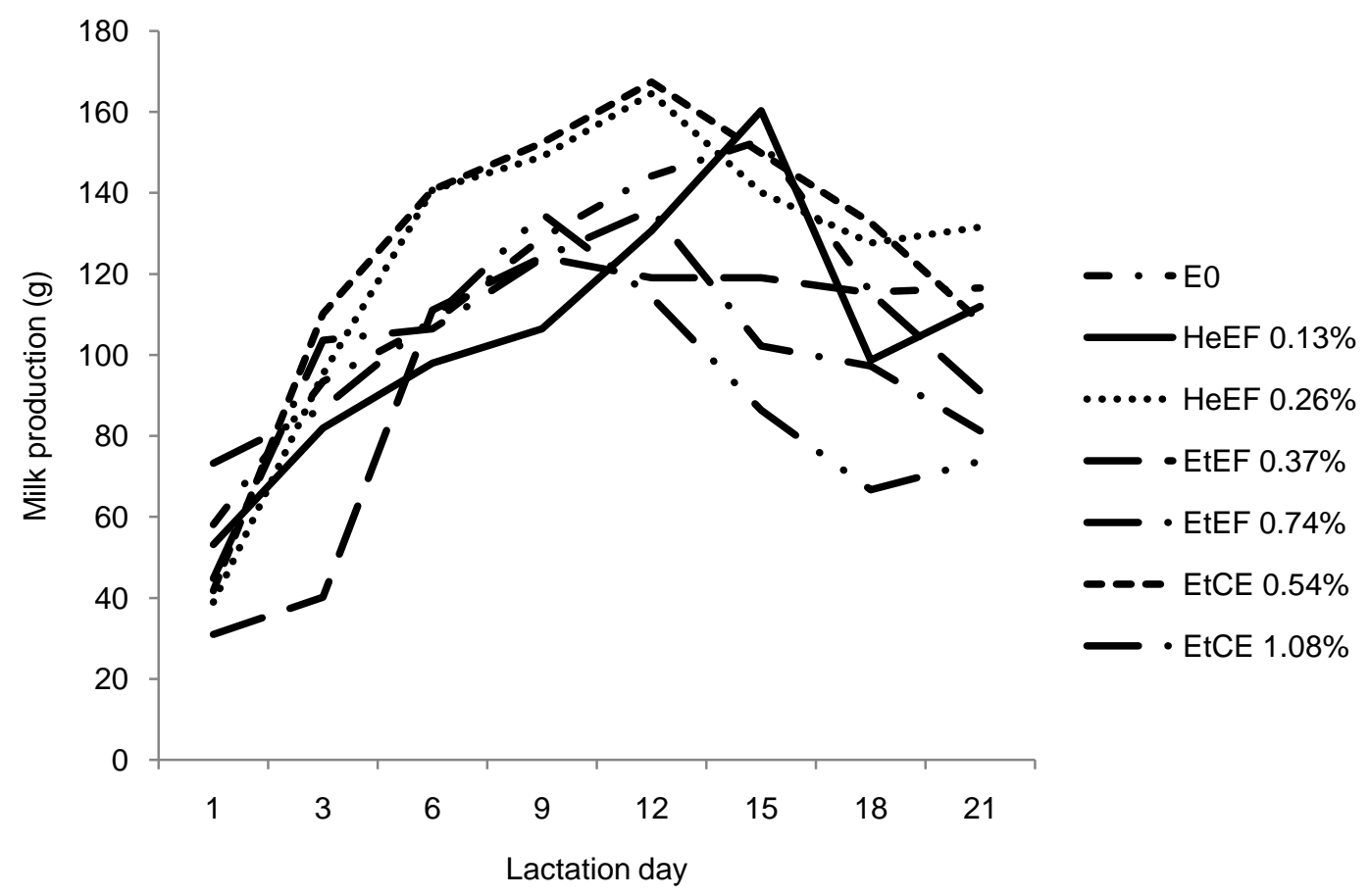

Figure 1 - The average daily milk production (g) up to $21^{\text {st }}$ day of lactation.

Differences in milk production are possible due to the effect of the bioactive compounds contained in MPL extract (Mutiara et al, 2013). It can be assumed that the compounds in hexane fraction extract had more effects on milk production than those in ethanol fraction. Based on the polarity of the solvents, hexane extract fraction contains phytosterol compounds while the ethanol crude extract compounds contain phytosterols and flavonoids in particular isoflavones (Anjani et al, 2003; Kudou et.al, 1991). Both of these compound groups have estrogenic activity (Ryokkynen, 2006). The $0.54 \%$ EtCE treatment containing phytosterol and isoflavone caused a significant increase in milk production at lower doses (which equal 10\% MPL in the feed), whereas $0.26 \%$ HeFE treatment increased milk production (which equal $20 \%$ MLP in the feed).

Phytosterols are compounds whose chemical structure is similar to cholesterol, which is a precursor of steroid hormones such as estradiol and progesterone, while isoflavones are compounds whose chemical structure is similar to estradiol. Suprayogi et.al (2009) reported that the hexane fraction of Sauropus androgynous leaves has higher galactagogue potency than the fraction of the water, acetyl acetate, and ethanol crude extracts. According to Xinmei, et al. (2015), the supplementation of phytosterol at cow early lactation increased milk production, milk composition, milk fat, lactoprotein, and total solids- non-fat. 


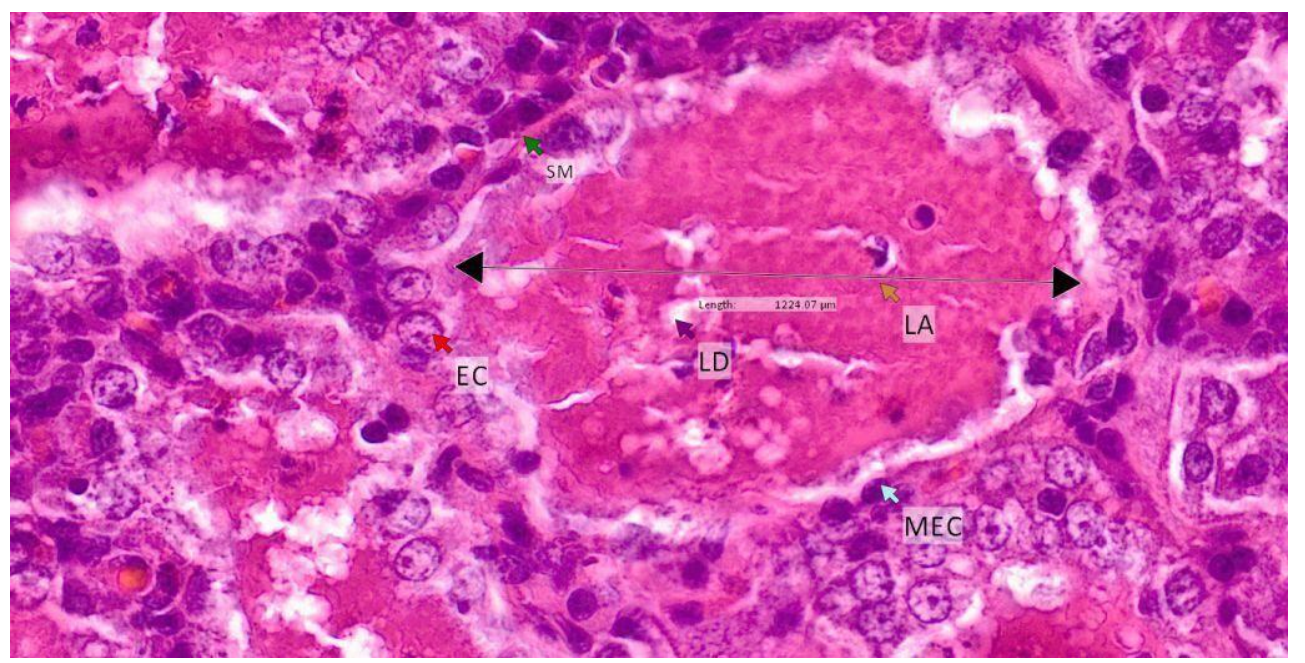

Figure 2 - The Histology of Lactating Doe's Mammary Gland, E0 (Control Treatment), 400x Enlargement ( $\mathrm{LA}=$ lumen of the alveolus. $\mathrm{EC}=$ epithelial Cell. MEC $=$ MioEpithelialCell. $L D=$ Lipid droplets. SM = Smooth Muscle. $\mathrm{S}=$ Stroma)

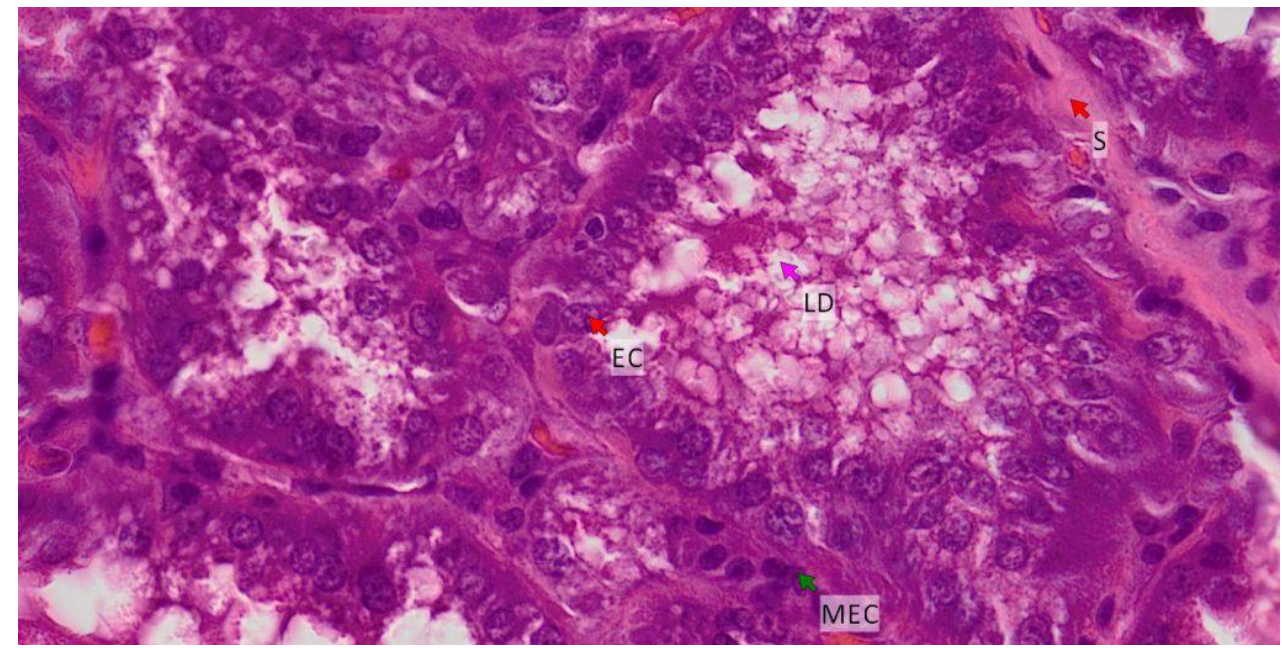

Figure 3 - The Histology of Lactating Doe's Mammary Gland, 0.26\% of HeEF Treatment, 400x Enlargement $(\mathrm{LA}=$ lumen of alveolus. $\mathrm{EC}=$ epithelial Cell. $\mathrm{MEC}=$ MioEpithelialCell.LD $=$ Lipid droplets. $\mathrm{SM}=$ Smooth Muscle. $\mathrm{S}=$ Stroma)

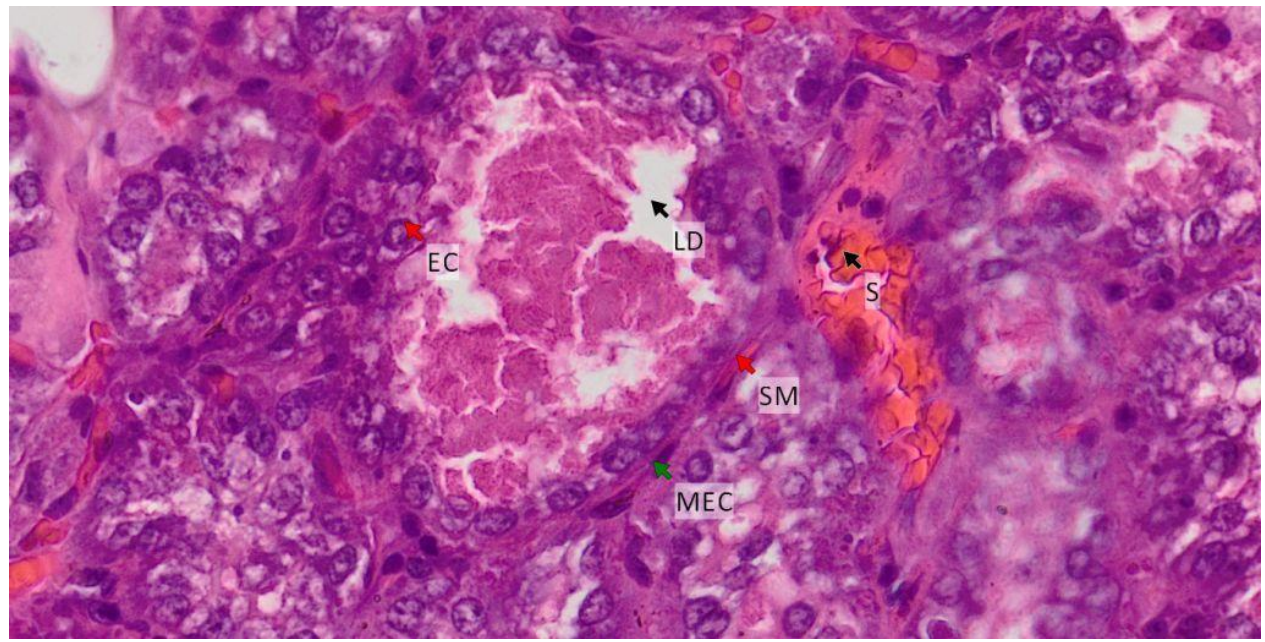

Figure 4 - The Histology of Lactating Doe's Mammary Gland, 0.54\% of EtCE Treatment, 400x Enlargement $(\mathrm{LA}=$ lumen of alveolus. $E C=$ epithelial Cell. $M E C=$ MioEpithelialCell. $L D=$ Lipid droplets. $\mathrm{SM}=$ Smooth Muscle. $\mathrm{S}=$ Stroma) 
Figure 2 to 4 show the mammary histology of some treatments. The histology can calculate the number of epithelial cells and alveoli, alveoli containing milk, and alveoli size using the extensive alveolar diameter of each treatment. Table 6 presents milk production, the number of epithelial cells, alveoli diameter and width per microscope field-of-view.

The $0.54 \%$ EtCE and $0.26 \%$ HeFE treatments causing higher milk production indicated several epithelial cells and active alveoli. The total alveoli at $0.26 \% \mathrm{HeFE}$ were $55.4 \pm 8.68$, with $89.53 \%$ active alveoli and the total alveoli at $0.54 \%$ EtCE were $59.2 \pm 6.94,95.27 \%$, which were actively producing milk. If $0.54 \%$ EtCE is compared with E0 (control) treatment, the former increased the number of active alveoli producing milk by $62.9 \%$, alveoli diameter by $49.75 \%$, and epithelial cells by $300 \%$.

Table 6 - The Number of Epithelial Cells, Diameter, and Width of the Alveoli per Microscope Field-of-view

\begin{tabular}{|c|c|c|c|c|c|c|}
\hline \multirow[b]{2}{*}{ Treatment } & \multirow{2}{*}{$\begin{array}{l}\text { Milk Production } \\
\text { (g/day) }\end{array}$} & \multirow{2}{*}{$\begin{array}{c}\text { Number of } \\
\text { epithelial cells }\end{array}$} & \multicolumn{3}{|c|}{ Number of the alveoli } & \multirow{2}{*}{$\begin{array}{l}\text { Average of alveolar lumen } \\
\text { diameter }(\mu \mathrm{m})\end{array}$} \\
\hline & & & Total & $\begin{array}{l}\text { With milk } \\
(\%)\end{array}$ & $\begin{array}{l}\text { Without } \\
\text { milk (\%) }\end{array}$ & \\
\hline E0 & $103.69 \pm 14.137^{a}$ & $12.39 \pm 4.8^{\mathrm{a}}$ & $47.6 \pm 8.96$ & 68.49 & 31.51 & $64.02 \pm 29.59$ \\
\hline HeEF0.13\% & $98.45 \pm 11.67^{\mathrm{a}}$ & $15.06 \pm 2.6^{\mathrm{ab}}$ & $55.4 \pm 8.68$ & 57.14 & 42.86 & $71.51 \pm 8.77$ \\
\hline $\begin{array}{l}\text { HeEF } \\
0.26 \%\end{array}$ & $128.83 \pm 10.11^{b}$ & $35.18 \pm 1.7^{c}$ & $46.2 \pm 12.56$ & 89.53 & 10.47 & $85.76 \pm 7.77$ \\
\hline EtEF $0.37 \%$ & $108.55 \pm 11.78^{a}$ & $19.96 \pm 2.09^{\mathrm{ab}}$ & $45.4 \pm 8.73$ & 53.74 & 46.26 & $78.62 \pm 11.02$ \\
\hline EtEF $0.74 \%$ & $96.46 \pm 12.35^{a}$ & $23.33 \pm 4.68^{\mathrm{b}}$ & $35.2 \pm 4.97$ & 77.84 & 22.16 & $96.51 \pm 4.59$ \\
\hline EtCE0.54 \% & $134.70 \pm 5.77^{\mathrm{b}}$ & $37.22 \pm 2.69^{C}$ & $59.2 \pm 6.94$ & 95.27 & 4.73 & $95.87 \pm 27.56$ \\
\hline EtCE $1.08 \%$ & $104.04 \pm 6.62^{\mathrm{a}}$ & $22.25 \pm 4.48^{\mathrm{b}}$ & $41.8 \pm 9.28$ & 66.51 & 33.49 & $68.56 \pm 8.84$ \\
\hline
\end{tabular}

*Superscript differences in the same column indicate significant differences $(P<0.05)$.

The difference of mammary gland figure in the treatments suggested the correlation between types and doses of phytosterols and isoflavones in each MLP extract. Phytosterols are compounds whose chemical structure is similar to cholesterol, which is a precursor of steroid hormones such as estradiol and progesterone; while isoflavones are compounds whose chemical structure is similar to estradiol and have estrogenic activity (Ryokkynen, 2006). The increasing milk production was possible due to the direct or indirect effect of compounds contained in MLP extract. The direct effect of estradiol formed from phytosterol stimulates the proliferation of myoepithelial cell and induce the maturation of mammary acini for milk production (Yart, et.al. 2013). The indirect effect was phytosterol stimulating anterior and posterior hypophysis to secrete oxytocin and prolactin. According to Santell et.al (1997), the isoflavones genistein and hormone estradiol administration in ovariectomized rats increased the level of prolactin in the blood. It is evident that there is a relationship between phytoestrogens and estradiol; it affects the secretion of the prolactin hormone, which brings an impact on milk production. Kleden et.al (2017) asserted that adding MLP in feed can increase prolactin in lactating does' blood.

Milk production is the result of a mechanism in the epithelial cells (endocytosis) and the release mechanism (exocytosis) (Trucket and Olliver, 2009) related to the prolactin and oxytocin hormones. The hypothalamus releases oxytocin hormone, encouraging epithelial cells contraction in the cell which allows milk secretion, while prolactin serves to maintain milk production (lactogenesis) (Lollivier et.al, 2006).

The estrogenic activity of phytosterol compounds can increase the estradiol and progesterone hormones. Progesterone stimulates the secretory formation in mammary gland while estradiol stimulates the posterior pituitary to secrete oxytocin that serves to release the milk and stimulates the anterior pituitary to secrete prolactin and growth hormone that serves to stimulate the growth of mammary glands and to stimulate milk production (Mutiara et.al, 2013).

Rabbits' mammary gland epithelial cells express oxytocin receptors and bind these receptors. There are two important effects on the mammary gland oxytocin: lactation is to accelerate the transfer of intracellular casein and to push myoepithelial cell contraction (Lollivier et.al, 2006). 


\section{CONCLUSION}

The ethanol crude extract of MLP containing phytosterol and isoflavone has greater potential as galactagogue than the ethanol and n-hexane fraction extracts. The milk production was increased by increasing the number of epithelial cells by $300 \%$, the alveoli producing milk by $63 \%$, and the diameter of alveoli by $50 \%$.

\section{ACKNOWLEDGMENTS}

We would like to express our gratitude to the leaders of the Indonesian Agency for Agricultural Research and Development Ministry of Agriculture who have funded this research.

\section{REFERENCES}

1. Almirante C.Y., C.H.N. Lim. 1996. The effectiveness of Natalac as A Galactagogue. JPMA 71 (3) January-March 1996. From Golacta.com.: 265-272

2. Antonette.M., E.A Hernandez. Benjamin G. 2003. A Comparative Study on The Efficacy of The Different Galactagogues Among Mothers with Lactational Insufficiency. J. Perinat. Assoc. Philipina; 30-37.

3. Akbar. M., SjofjanO.Minarti S. 2013. Production of Milk and Mortality Rate of Bunnies Were Feed with Added Sauropus androgynus Leaves Flour. Jurnal IImu Ternak dan Veteriner. 18 (4): 233-238.

4. Alemede.I.C. E.A. Onyeji. D.N. Tsado. E.L. Shiawoya. 2014. Reproductive Response of Rabbits Dose to Diets Containing Varying Levels of Horseradish (Moringa oleifera) Leaf Meal. J. Biol.Agr.Healthcare. 4 (19): 62-68

5. Estrella.Ma.,Corazon P.M.D., Jacinto Blas V. Mantaring III.M.D. Grace Z. David.M.D. Michelle A. Taup.M.D. 2000. A Double-blind. A randomized controlled trial on the use of malunggay (Moringa oleifera) for augmentation of the volume of breastmilk among nonnursing mothers of paterm infants. Galacto.Com. Philippine J. Ped.49: 3-6.

6. Ferreira.P.M.P. D.F. Farias.J.T. de A. Olivera and A. de F. U. Carvalho. 2008. Moringaoleifera: bioactive compounds and nutritional potential. Rev. Nutr. Campinas. 21 (4); $431-437$.

7. Foidl.N.,Makkar .H.P.S and Becker. K. 2001. The Potential of Moringa oleifera for Agricultural and Industrial Uses. In. Fugile.L.J. The Miracle Tree: The Multiple Attributes of Moringa. CTA.Publication.Wanegen. The Netherlands: 45-76

8. Halls. Amy E. 2010. Nutritional Requirement for Rabbits.Shur-Gain. Nutreco Canada Inc.

9. Kleden. M.M., H. Soetanto, Kusmartono, Kuswanto. 2017. The concentration of Progesterone and Prolactin Hormones and Milk Production of New Zealand White Rabbits Doe Fed MLP. Mediterranean J. Soc. Sci. MJSER PublishingRome-Italy.Vol 8 No 3.Doi. 10.5901/mjss.2017.v8n3p79.

10. Konar, N., E.S. Poyrazoĝlu, K. Demir, and N. Artik. 2012. Determination of Conjugated and Free Isoflavones in Some Legumes by LC-MS/MS. J.of Food Compos. Anal. 25 (2): 173-78. Doi: 10.1016/j.jfca. 2011.11.004.

11. Kudou.S., Y. Fleury. D. Welti. D. Magnolato. T. Uchida. K. Kitamura.andK. Okubo. 1991. Malonylisoflavone glycosides in soybean seeds (Glycine max Merrill). J. Agri. and Biol. Chem. 55: 2227-2233.

12. Leone, A., A Spada. A Battezzati, ASchiraldi, J Ariistil, and S Bertoli. 2015. Cultivation.Genetic.Ethnopharmacology.Phytochemistry and Pharmacology of Moringaoleifera Leaves: An Overview. Int. J. Mol. Sci. 16: 12791-12835

13. Lollivier V., P.G Marnet., S Delpal.D. Rainteau.CAchard, ARabot, and M.O.Bousquet. 2006. Oxytocin stimulated secretory processes in lactating rabbit mammary epithelial cells. J. Physiol. 570 (1); 125-140.

14. Mendieta-Araica, B., Spörndly, R., Reyes-Sánchez, N. and Spörndly, E., 2010. Moringa (Moringaoleifera) leaf meal as a source of protein in locally produced concentrates for 
dairy cows fed low-protein diets in tropical areas, Livestock Science, DOI: 10.1016/j.livsci.2010.09.021

15. Mendieta-Araica.B.E.Spörndly. N. Reyes-Sánchez \& R. Spörndly. 2011. Feeding Moringaoleifera fresh or ensiled to dairy cows-effects on milk yield and milk flavor. Trop Anim Health Prod.43: 1039-1047

16. Miller, M. and W. Schute. 2010. Measuring Phytosterol in Health Supplement by LC/MS. Thermo Fisher Scientific. San Jose. CA. USA

17. Mutiara K.T., Harijono, T. Estiasih, E.S. Wahyuni. 2013. Effect LactagogueMoringa Leaves (MoringaoleiferaLam) Powder in Rats White Female Wistar. J. Basic. Appl. Sci. Res. 3(4)430-434.

18. Rajagopal.P.L., K.Premaletha, and K.R.Sreejith. A Comprehensive Review On Safe Galactagogues. 2016.WorldJ. Pharm. Res. 5 (8): 1629-1640

19. Ryokkynen, A. 2006. Effects of Phytoestrogens on Reproduction and Weight Regulation of Mammals. Dissertations in Biology. The University of Joensuu.

20. Roland, W.S.U.,. R.J. Gouka, H. Gruppen, M. Driesse, L. van Buren, G. Smith and J. Vinken, 2014. 6-Methoxyflavanones as Bitter Taste Receptor Blockers for hTAS2R39. PLOS One. (9): 1-10

21. Sanchez.N.R., J. EvaSpo“ rndly., I. Ledin. 2006. Effect of feeding different levels of foliage of Moringa oleifera to creole dairy cows on intake, digestibility, milk production and composition. Livest. Sci. 24-31

22. Santell, R.C., Y.C. Chang, M.G. Nair, and W.G. Helferich. 1997. Dietary Genistein Exerts Estrogenic Effects Upon The Uterus, Mammary Gland And The Hypothalamic/Pituitary Axis In Rats. J. Nutr. 127 (2): 263-269.

23. Soetanto.H., S. Chuzaemi.and E. Marhaeniyanto.2010. Performance of growing goats with and without supplementation of Moringa leaves at Pasrujambe village, the regency of Lumajang. EastJava. Proceedings of International Seminar on Prospects and challenges of Animal Production in Developing Countries in the 21 Century.

24. Suprayogi A, N Kusumorini, MA Setiadi, dan YB Murti. 2009. Production of standarised Sauropus androgynus (L.) leaves extract as a raw material for nutrion repair, reproduction and lactation improvement. Final report of LPPM Research Institute Agricultural of Bogor.

25. Steel, R.G.D. and J.H. Torrie. 1980. Principles and Procedures of Statistics with Reference to the Biological Sciences. McGraw Hill, New York.

26. Wadha S.M.S.,Panwar.N., SainS Rawat and S.Singhai. 2013. A Review on Commercial Traditional Phytoconstituents and Pharmacological Activity of Moringa oleifera. Global J. Traditional Med. Syst. 2(1): 1-13

27. Xinmei, X., X. Ning, H. Jianbin. 2015. Physiological Function of Phytosterol and Its Application. Anim. Husb. Feed Sci. 7 (2): 67-69. DOI: 10.1007/s13398-014-0173-7.2.

28. Yart. L. Finot. L. Lollivier. V.\& Dessauge. F. (2013). Oestradiol enhances apoptosis in bovine mammary epithelial cells in vitro. J. Dairy Res.80(1). 113-21. https: //doi.org/10.1017/S0022029912000714

29. Zuppa A., A. Sindico, P. Orchi, C. Carducci. V. Cardiello. C.Romagnoli and P. Catenazzi. 2010. Safety and Efficacy of Galactogogues: Substances that Induce maintain and Increase Breast Milk Production. J. Pharm. Pharmaceut Sci. 13(2) 162-174. 